\title{
Biographical note of Professor Jacek Łuczak
}

Palliat Med Pract 2019; 13, 4: 263-266

Professor Jacek Łuczak, the founder of palliative and hospice care in Poland, died in Poznań on 22 May 2019. Professor's profile and his key achievements are worth recalling.

Professor of medicine Jacek Józef Łuczak, Ph.D. - a physician, specialist in internal medicine, anaesthesiology and intensive care, cardiology and palliative medicine, was born on 30 December 1934 in Poznań. Professor died on 22 October 2019 in Poznań, on the day of remembrance of St. John Paul II. He was a son of a professional officer of the Second Polish Republic. When World War II broke out, he was 5 years old and spent the occupation in Poznań. In 1953, he graduated from Karol Marcinkowski Junior High School. In 1959, was a graduate of the Department of Medicine at the Poznań University of Medical Sciences. Professor Jacek Łuczak's professional resume is extensive.

Since 1965, he was employed at the Poznań University of Medical Sciences (now the Karol Marcinkowski University of Medical Sciences in Poznań), initially as an assistant at the I Clinic of Internal Medicine of the Pavlov Hospital (now the Clinical Hospital of Lord's Transfiguration of the University of Medical Sciences in Poznań). One of the many merits that should be remembered while mentioning this period of Professor's work was the organisation of the first in Wielkopolska and the third in Poland Cardiac Resuscitation Unit at the Clinical Hospital of Lord's Transfiguration of the University of Medical Sciences in Poznań. In 1967-1970, Professor Jacek Łuczak was the first head of that department. In 1978-1984, he headed a team of anaesthesiologists cooperating with the Clinic of Gastroenterological Surgery of the Heliodor Święcicki Clinical Hospital in Poznań.

In 1981, he was instituted a Dean of the Department of Medicine of the Poznań University of Medical Sciences in free elections during the Solidarity period. He was dismissed from this postion after several months, during the period of martial law, at the request of the Minister of Health - the decision was justified by: "negative impact on the environment".

In the 1980's, Professor was the organiser and the first Head of the Emergency Department (now the Department of Teaching Anaesthesiology and Intensive Therapy). Professor developed a first curriculum for medical students at the University of Poznań and, as an editor, prepared the first academic book for students in the field of emergency aid.

\section{Development of palliative care, key achievements}

In 1985-1990, Professor Jacek Łuczak was the Head of the Team of Anaesthesiologists at the Oncology Clinic. In 1987, he established the Pain Management Centre with Ambulance Team at the hospital at Łąkowa 1/2 Street, which was part of the Pavlow

\footnotetext{
Address for correspondence:

Wojciech Leppert

Laboratory of Quality of Life Research

Poznan University of Medical Sciences

Osiedle Rusa 55, 61-245 Poznań

phone/fax: + 48618738303

e-mail: wojciechleppert@wp.pl
} 
Clinical Hospital No. 1 at ul. Długa 1 in Poznań. It was a very innovative activity in Poland, as well as in Central and Eastern Europe. Personally, accompanied by a nurse from an anaesthetic team or from an Oncology Clinic, he frequently visited home patients. The patients were usually registered by their families (medical registration was rare at that time). The number of visits and patient reports grew rapidly.

In 1990, Professor Jacek Łuczak established the first 7-bed Terminal Ward in the public health care system in Poland and Central and Eastern Europe, while in 1991 - the first academic unit of palliative care in Poland and Central and Eastern Europe - the Clinic of Palliative Care, Anaesthesiology and Oncological Intensive Therapy at the Chair of Oncology of the University of Medical Sciences in Poznań, transformed into the Chair and Clinic of Palliative Medicine of the Karol Marcinkowski University of Medical Sciences in Poznań (2002). Professor Jacek Łuczak was in executive position from 1991 to his retirement in 2005. Palliative medicine education was introduced into the curriculum of 6 th year medical students of the academic year 1990/1991. In the following years, the training of students was extended to students of health sciences (nursing major), then by those of physiotherapy and medical rescue service. As the first medical school in Poland, palliative care was taught to foreign medical students in the English language (English Teaching Centre).

Simultaneously, an increasing number of patients could benefit from the assistance of a specialist home care team, thanks to the persistent work of an interdisciplinary team of doctors, nurses, psychologists, social workers and volunteers. In 1997, in an article presenting the development of palliative care units in Central and Eastern Europe, Professor David Clark considered the Palliative Care Clinic in Poznań as one of the 5 leading model centres - "beacons in palliative care". [1].

During the first pioneering years of activity, it was important to develop principles for effective and safe pain treatment with opioids, especially in home patients. Professor's merit was, inter alia, the development of a method of morphine preparation and dosing in the form of an aqueous solution, which was used for many years as the only opioid analgesic of the 3rd step of the WHO analgesic ladder available in Poland, bringing relief to many thousands of patients.

In 1988, Professor Jacek Łuczak took an internship in the Institute of Oncology in Milan - a palliative care centre cooperating with WHO, led by Vittorio Ventafridda (EAPC, President of the European Association for Palliative Care). Professor introduced into the practice of many palliative and hospice care teams the method of administering morphine subcutaneously with a but- terfly needle, in a mixture with other supportive drugs used to treat symptoms such as nausea and emesis, dyspnoea, disturbances of consciousness, in patients in whom oral administration of drugs was ineffective or impossible. This simple method made it possible to avoid the need to repeat painful intramuscular injections, which resulted in additional, significant discomfort for patients.

In 1993, Professor Łuczak established the Palliative Care Intervention Team, comprising of a doctor and a nurse, who provided assistance to patients on weekdays, in the afternoon and at night, and 24 hours a day on public holidays - it was a very innovative activity at that time, which currently functions as a Home Hospice, providing 24/7 palliative care in patient's homes.

In 1997, the Palium Hospice, located at the Rus Housing Estate in Poznań, in a building that was originally intended to be a District Clinic, started operating. The building was thoroughly rebuilt and, as far as possible, adapted to the conditions of optimal functioning. Initially, the Day Terminal Ward was established on its premises. In 2001, the Terminal Ward (it initially housed 15 beds), together with the Palliative Medicine Clinic with Home Care Team (which was later transformed into the Home Hospice), was transferred from the hospital at ul. Łąkowa. In addition, Pain Management Clinic, Wound Management Clinic and Rehabilitation Unit were established. The Palium Hospice, extended in the following years, has currently the Terminal Ward for 40 patients, and provides care for over 1200 patients annually, in terms of the Home Hospice. Professor was the Head of the Terminal Ward of the Palium Hospice until the end of his life.

Professor Jacek Łuczak was an indefatigable organiser and promoter of palliative and hospice care. In Poznań, Professor organised the first Palliative Care Conference in Poland (1988). He initiated and conducted, together with a team, extensive educational activity throughout Poland, which led to the establishment of several dozen palliative care units in almost the whole country in the 1990s, within the structures of public health care. On the initiative of Professor Łuczak, in 1994, the Ministry of Health published a monograph "Fighting Cancer Pain" with the circulation of 300 thousand copies, sent to Polish physicians. Authors of this publication: Janina Kujawska-Tenner, Jacek Łuczak, Małgorzata Okupny, Aleksandra Kotlińska and Tomasz Dangel presented the current knowledge on treating cancer pain [2].

Since 1989, Professor Łuczak organised annual Conferences on palliative care with the participation of renowned palliative care experts, followed by numerous palliative care courses both in Poznań and 
other Polish cities, especially in places where palliative care teams and hospices were established.Since 1991, Professor Jacek Łuczak worked with the Ministry of Health and Social Welfare in organising palliative care throughout the country. Thanks to Professor and Reader Janina Kujawska-Tenner from Kraków, in 1999 in Poland, as the third country in Europe after Great Britain and Ireland, a medical specialisation in palliative medicine was established, and a few years later, a specialisation in palliative care nursing. As a result of cooperation with the Minister of Health, Krajowa Rada Opieki Paliatywnej i Hospicyjnej [the National Council for Hospice and Specialist Palliative Care Services] was established on 25 October 1993. Professor Jacek Łuczak was the President for all three terms of office - until 2003. As a result of his efforts, in 1994, the Minister of Health established the position of National Consultant in Palliative Medicine, which Professor Łuczak held in the years 1994-2001, and then the positions of Voivodeship Consultants in palliative medicine in all 16 Voivodeships were created.

In 1992, Professor prepared the first Programme for the Development of Palliative Care in Poland, another one, developed by the National Council for Hospice and Specialist Palliative Care Services in 1999, was adopted as an official document of the Ministry of Health. Thanks to his and Father Eugeniusz Dutkiewicz's efforts, palliative care services have been contracted since 1999, initially by the Sickness Funds and included in guaranteed medical services, until now contracted by the National Health Fund.

In 1989, Professor Łuczak established one of the first Associations in Poland aimed at developing palliative care: Aleksander Lewiński and Antonina Mazur Polish Palliative Care Society. He was a long-time President of the Executive Board until 2000 and from the moment of its establishment in 1996 until the end of his life - the President of the Polish Palliative Care Society Branch in Poznań.

\section{International activities}

Professor Jacek Łuczak actively participated in numerous meetings and international conferences on palliative care. In the 1990s, he initiated and organised, together with Professor Robert Twycross and Dr Michael Minton from Sir Michael Sobell House Hospice in Oxford, a centre cooperating with the World Health Organisation, annual palliative care training courses for physicians and nurses from Poland and Central and Eastern European countries, where the lecturers were the European and world authorities in the field of palliative care, i.a. Professor Sam H. Ahmedzai,
Professor Irene Higginson, Professor Kathleen Foley, Professor Declan Walsh, Professor Steven Passik and Dr. Zbigniew Żylicz, Professor at the University of Rzeszów. In total, in the years 1994-2000, approximately 800 participants attended these courses: physicians, nurses and psychologists from, i.a., the Czech Republic, Slovakia, Serbia, Croatia, Hungary and Romania.

Thanks to the initiative of Professor Jacek Łuczak in the 1990s, with the support of Polish Hospices Found and Gillian and Muir Hunter, over 100 physicians from all over Poland have been trained in some of the leading hospices in the UK.

Professor was the initiator of the establishment in 1999 of the Central - Eastern Palliative Care Task Force (ECEPT), which conducted extensive educational activities for physicians and other employees of newly established palliative care units, who participated in courses and internships at the Palliative Care Centre in Poznań and other leading palliative and hospice care centres in Poland. Professor was acting as the President of ECEPT.

\section{Scientific development path}

In 1971, Professor Jacek Łuczak was awarded the MD, PhD title for his work "Clinical evaluation of fentanyl and dehydrobenzperidol in acute myocardial infarct" [3]. In 1978, he was awarded the degree of Professor, MD, PhD following the thesis entitled "The impact of a respirator and anaesthetics on the size of experimental myocardial infarct in dogs". He was awarded the title of Associate Professor in 1999 and the title of Full Professor in 2002.

Professor is the Author or Co-author of approximately 600 scientific papers, published in Polish and foreign journals, a supervisor of 10 doctoral theses in palliative medicine, and has educated 3 independent academic employees, including one professor and two readers.

In 2010, the World Academy of Medicine awarded Professor Jacek Łuczak the honoris causa doctorate.

\section{Awards and distinctions}

In 1999, in recognition of his merits in developing palliative and hospice care, he was awarded a Fellowship in Royal College of Physicians (FRCP) in London. He was repeatedly awarded with prestigious distinctions by the Ministry of Health, the city of Poznań and other organisations:

The Title of the Distinguished Citizen of Wielkopolska in 1991, in the plebiscite of Radio Mercury; in 1993 - Karol Marcinkowski honorary medal, in 2002 - Amicus Hominis and Veritatis; in 
2003 - "Healthcare Person of the Year 2003 — Public Health"; in 2009 - ECCE Homo title; in 2012, the title of "Man of the Year 2012" in the "'Medical Leaders" plebiscite organised by Głos Wielkopolski; in 2012, he received the European Citizens' Prize; in 2013 - Ryszard Kapuściński Award of Wielkopolska Region; in 2015, he was awarded the title of Wielkopolska Brand Ambassador; in 2016 - Golden Academic Laurel; in 2017, he was honoured in the competition Wielkopolski Lekarz z Sercem im. Kazimierza Hołogi. Particularly noteworthy is the European Parliament Citizen's Prize for services to the development of palliative care in Poland and worldwide, received in 2014.

On 14 September 2019, during the Conference of the 30th Anniversary of the Polish Palliative Care Society in Poznań, Professor Łuczak was awarded the Commander's Cross of the Order of Polonia Restituta by the President of the Republic of Poland.

The real contribution of Professor were his meetings with hundreds or maybe even thousands of patients and their families, with whom he was able to establish exceptional relationships, taking care of their needs and expectations, responding to their numerous anxieties and doubts. He could go beyond his medical or academic duties in a variety of ways. What distinguished him was his openness, his ability to listen to and accompany a suffering person.

\section{Non-medical interests}

Professor Jacek Łuczak was a licensed Poznań Guide since the 1950s, a passionate bridge player and a co-founder of "Surma" - the first sports bridge section in Poznań, at the Poznań Palm House. He was a loyal supporter of "Kolejorz" - Lech Poznań football team, popular in Poznań and in Poland, also recognised abroad. He was interested in history, especially the period of the September Campaign and
World War II. He liked music. His lectures were often held with background music.

\section{Farewell}

We will remember Professor as he approached the patients, sat on their beds, greeted them by shaking their hands or, frequently, kissing the patients, and talked to them and their relatives for a long time. Conversation was a very important part of diagnosis and treatment. He said that "the patient is the most important" and this was really the case. He was an outstanding clinician, with great medical knowledge and intuition, an extremely honest physician, always treating every patient and family subjectively, irrespective of their family or material situation. He had a great influence on the development of humanistic medicine, not only in the field of palliative care, but of the whole medicine both in Poland and abroad.

Professor's last journey took place on 31 October 2019 at the Junikowo Cemetery in Poznań, preceded by the Holy Mass in the Poznań Cathedral, said by Bishop Zdzisław Fortuniak and many priests. The celebrations were attended by many people representing palliative care units and hospices from all over Poland, as well as numerous representatives of the authorities of the City of Poznań and Wielkopolska Region.

Professor will remain forever in our grateful memory and in our hearts.

\section{References}

1. Clark, D., Hockley, J., Ahmedzai, S. New Themes in Palliative Care, Buckingham Philadelphia 1997.

2. Kujawska-Tenner, J., Łuczak, J., Okupny, M., et al. Zwalczanie bólów nowotworowych [Fignting Cancer Pain]. Ministry of Health and Social Welfare, Warsaw 1994.

3. Łuczak, J. Clinical evaluation of fentanyl and dehydrobenzperidol in acute myocardial infarct. Kardiol. Pol. 1972; 15 (3): 299-306. 


\title{
Biogram Pana Profesora Jacka Euczaka
}

Artykuł jest tłumaczeniem pracy: Bogusz H., Leppert W., Kotlińska-Lemieszek A., Biographical note of Professor Jacek Łuczak. Palliat. Med. Pract. 2019 tom 13, nr 4: 263-266.

Należy cytować wersję pierwotną.

Piśmiennictwo znajduje się na stronie 266.

W dniu 22 października 2019 roku zmarł w Poznaniu Świętej Pamięci Pan Profesor Jacek Łuczak, twórca opieki paliatywnej i hospicyjnej w Polsce. Warto przypomnieć sylwetkę Pana Profesora i jego najważniejsze osiągnięcia.

Profesor doktor habilitowany medycyny Jacek Józef Łuczak - lekarz, specjalista z zakresu chorób wewnętrznych, anestezjologii i intensywnej terapii, kardiologii i medycyny paliatywnej, urodził się 30 grudnia 1934 roku w Poznaniu. Profesor odszedł w dniu 22 października 2019 roku w Poznaniu, w dniu wspomnienia Świętego Jana Pawła II. Był synem oficera zawodowego II Rzeczpospolitej, kiedy wybuchła II wojna światowa miał 5 lat, okupację spędził w Poznaniu. W 1953 roku ukończył Gimnazjum im. Karola Marcinkowskiego, w 1959 roku został absolwentem Wydziału Lekarskiego Akademii Medycznej w Poznaniu. Życiorys zawodowy Pana Profesora Jacka Łuczaka jest bardzo bogaty.

Od 1965 roku zatrudniony w Akademii Medycznej w Poznaniu (dzisiejszy Uniwersytet Medyczny im. Karola Marcinkowskiego w Poznaniu), początkowo jako asystent w I Klinice Chorób Wewnętrznych Szpitala im. Pawłowa (obecnie Szpital Kliniczny Przemienienia Pańskiego UM w Poznaniu). Jedną z wielu zasług, którą należy przypomnieć wspominając ten okres pracy Pana Profesora, było zorganizowanie pierwszego w Wielkopolsce i trzeciego w Polsce Oddziału Reanimacji
Kardiologicznej w Szpitalu Klinicznym Przemienienia Pańskiego w Poznaniu. W latach 1967-1970 Pan Profesor Jacek Łuczak był pierwszym ordynatorem tego oddziału. W latach 1978-1984 kierował zespołem anestezjologów współpracujących z Kliniką Chirurgii Gastroenterologicznej Szpitala im. Heliodora Święcickiego w Poznaniu.

W 1981 roku w wolnych wyborach w okresie Solidarności został wybrany Dziekanem Wydziału Lekarskiego Akademii Medycznej w Poznaniu, został odwołany ze stanowiska po kilkunastu miesiącach, w okresie stanu wojennego, na polecenie Ministra Zdrowia - w uzasadnieniu wpisano „negatywny wpływ na środowisko".

W latach 80-tych Pan Profesor był organizatorem i pierwszym Kierownikiem Zakładu Pomocy Doraźnej (dzisiejszy Zakład Dydaktyki Anestezjologii i Intensywnej Terapii). Pan Profesor opracował pierwszy na poznańskiej uczelni program nauczania studentów medycyny i przygotował, jako Redaktor, pierwszy skrypt dla studentów z zakresu pomocy doraźnej.

\section{Rozwój opieki paliatywnej — najważniejsze osiągnięcia}

W latach 1985-1990 Pan Profesor Jacek Łuczak był Kierownikiem Zespołu Anestezjologów przy Klinice

\author{
Adres do korespondencji: \\ Wojciech Leppert \\ Pracownia Badania Jakości Życia \\ Katedra i Klinika Medycyny Paliatywnej \\ Uniwersytet Medyczny im. Karola Marcinkowskiego w Poznaniu \\ Osiedle Rusa 55, 61-245 Poznań \\ tel./faks: + 48618738303 \\ e-mail: wojciechleppert@wp.pl
}


Onkologii i tutaj w 1987 roku założył Poradnię Walki z Bólem z Zespołem Wyjazdowym w Szpitalu przy ul. Łąkowej 1/2, który stanowił część Szpitala Klinicznego nr 1 im. Pawłowa przy ul. Długiej 1 w Poznaniu. Była to działalność niezwykle nowatorska w Polsce i w Europie Środkowo-Wschodniej. Osobiście, często w towarzystwie pielęgniarki z zespołu anestezjologicznego lub Kliniki Onkologii, odwiedzał chorych przebywających w domach. Chorzy byli zgłaszani $z$ reguły przez rodziny (zgłoszenie lekarskie było $w$ tym okresie rzadkością). Liczba zgłoszeń pacjentów i wizyt rosła w szybkim tempie.

W 1990 roku Pan Profesor Jacek Łuczak założył pierwszy w publicznym systemie opieki zdrowotnej w Polsce i w Europie Środkowo-Wschodniej 7-łóżkowy Oddział Opieki Paliatywnej, a w 1991 roku, podobnie, pierwszą w Polsce i w Europie Środkowo-Wschodniej, jednostkę akademicką opieki paliatywnej - Klinikę Opieki Paliatywnej, Anestezjologii i Intensywnej Terapii Onkologicznej przy Katedrze Onkologii Akademii Medycznej w Poznaniu, przekształconą w 2002 roku w Katedrę i Klinikę Medycyny Paliatywnej Uniwersytetu Medycznego im. Karola Marcinkowskiego w Poznaniu. Pan Profesor Jacek Łuczak nieprzerwanie pełnił funkcję Kierownika od 1991 roku do przejścia na emeryturę w 2005 roku. Kształcenie w dziedzinie medycyny paliatywnej zostało wprowadzone do programu nauczania studentów medycyny VI roku w roku akademickim 1990/1991. W kolejnych latach szkolenie studentów rozszerzono na studentów nauk o zdrowiu (kierunek pielęgniarstwo), następnie fizjoterapii i ratownictwa medycznego. Jako w pierwszej uczelni medycznej w Polsce, nauczaniem z zakresu opieki paliatywnej objęto studentów medycyny z innych krajów w języku angielskim (Ośrodek Nauczania w Języku Angielskim).

Jednocześnie coraz większa liczba chorych mogła korzystać z pomocy specjalistycznego zespołu opieki domowej, dzięki wytrwałej pracy interdyscyplinarnego zespołu lekarzy, pielęgniarek, psychologów, pracowników socjalnych i wolontariuszy. W roku 1997 roku Pan Profesor David Clark w artykule przedstawiającym rozwój jednostek opieki paliatywnej w Europie Środkowo-Wschodniej uznał Klinikę Opieki Paliatywnej w Poznaniu za jeden z 5 wiodących wzorcowych ośrodków-latarni w opiece paliatywnej „Beacons in palliative care" [1].

W okresie pierwszych pionierskich lat działalności istotne było opracowanie zasad skutecznego i bezpiecznego leczenia bólu przy zastosowaniu opioidów, zwłaszcza u chorych pozostających w domach. Zasługą Pana Profesora było między innymi opracowanie sposobu przygotowania i dawkowania morfiny w postaci roztworu wodnego, która przez wiele lat była stosowana, jako jedyny analgetyk opioidowy 3 stopnia drabiny analgetycznej WHO dostępny w Polsce, przynosząc ulgę wielu tysiącom chorych.

W 1988 roku Pan Profesor odbył staż w Instytucie Onkologii w Mediolanie, ośrodku opieki paliatywnej współpracującym z WHO, kierowanym przez Pana Profesora Vittorio Ventafridda (EAPC, Prezesa Europejskiego Towarzystwa Opieki Paliatywnej), Pan Profesor Jacek Łuczak wprowadził do praktyki wielu zespołów opieki paliatywnej i hospicyjnej metodę podawania morfiny drogą podskórną przez igłę typu „motylek" w mieszaninie $z$ innymi lekami wspomagającymi stosowanymi w leczeniu objawów, takich jak nudności i wymioty, duszność, zaburzenia świadomości, stosowanych w leczeniu pacjentów, u których podawanie leków drogą doustną było nieskuteczne lub niemożliwe. Ta prosta metoda pozwoliła na uniknięcie konieczności powtarzania bolesnych iniekcji drogą domięśniową, co powodowało dodatkowy, znaczny dyskomfort dla chorych.

W 1993 roku Pan Profesor Łuczak powołał Zespół Interwencyjny Opieki Paliatywnej, w skład którego wchodzili lekarz i pielęgniarka, którzy zabezpieczali pomoc chorym w dni powszednie w godzinach popołudniowych i nocnych oraz całodobowo w dni wolne od pracy - było to wówczas bardzo innowacyjne działanie, które obecnie funkcjonuje jako Hospicjum Domowe, zapewniające całodobową opiekę paliatywną w domach chorych.

W 1997 roku rozpoczęło działalność Hospicjum Palium na Osiedlu Rusa w Poznaniu w budynku, który pierwotnie miał być Przychodnią Rejonową, a który gruntownie przebudowano i, w miarę istniejących możliwości, dostosowano do warunków optymalnego funkcjonowania. Na jego terenie powstał początkowo Oddział Dzienny Opieki Paliatywnej. W 2001 roku przeniesiono ze Szpitala przy ul. Łąkowej Oddział Medycyny Paliatywnej (początkowo liczył 15 łóżek) z Poradnią Medycyny Paliatywnej z Zespołem Opieki Domowej, przekształconym następnie w Hospicjum Domowe. Ponadto, utworzono Poradnię Leczenia Bólu, Poradnię Leczenia Ran i Oddział Rehabilitacji. Hospicjum Palium, rozbudowywane w kolejnych latach, obecnie dysponuje Oddziałem Medycyny Paliatywnej dla 40 chorych i obejmuje opieką ponad 1200 pacjentów rocznie w ramach Hospicjum Domowego. Pan Profesor pełnił do końca życia obowiązki Lekarza Kierującego Oddziałem Medycyny Paliatywnej Hospicjum Palium.

Pan Profesor Jacek Łuczak był niestrudzonym animatorem i propagatorem opieki hospicyjnej i paliatywnej. W 1988 roku w Poznaniu zorganizował pierwszą w Polsce Konferencję poświęconą opiece paliatywnej. Zainicjował i wraz z zespołem prowadził szeroką działalność edukacyjną w całej Polsce, co doprowadziło do utworzenia w latach 90. kilkudzie- 
sięciu jednostek opieki paliatywnej w niemal całym kraju, w strukturach publicznej ochrony zdrowia. Z inicjatywy Pana Profesora Łuczaka w 1994 roku została wydana przez Ministerstwo Zdrowia monografia "Zwalczanie bólów nowotworowych" w nakładzie 300 tysięcy egzemplarzy rozesłaną do lekarzy w Polsce. Autorzy publikacji: Janina Kujawska-Tenner, Jacek Łuczak, Małgorzata Okupny, Aleksandra Kotlińska i Tomasz Dangel, przedstawili aktualną wiedzę dotyczącą leczenia bólu u chorych na nowotwory [2].

Od 1989 roku Profesor Łuczak organizował coroczne Konferencje opieki paliatywnej z udziałem cenionych ekspertów opieki paliatywnej, a następnie bardzo liczne kursy opieki paliatywnej zarówno w Poznaniu, jak i w innych miastach Polski, zwłaszcza w miejscowościach, w których tworzono zespoły opieki paliatywnej i hospicja.Od 1991 roku Pan Profesor Jacek Łuczak współpracował z Ministerstwem Zdrowia i Opieki Społecznej w zakresie organizowania opieki paliatywnej w całym kraju. Dzięki Panu Profesorowi i Pani Docent Janinie Kujawskiej-Tenner z Krakowa w 1999 roku utworzono w Polsce, jako w trzecim kraju w Europie po Wielkiej Brytanii i Irlandii, specjalizację lekarską w dziedzinie medycyny paliatywnej, a po kilku latach, specjalizację pielęgniarstwa opieki paliatywnej. Efektem współpracy z Ministrem Zdrowia było powołanie 25 października 1993 roku Krajowej Rady Opieki Paliatywnej i Hospicyjnej (KROPiH). Pan Profesor Jacek Łuczak był Przewodniczącym przez wszystkie trzy kadencje — do 2003 roku. Dzięki Jego staraniom w 1994 roku Minister Zdrowia utworzył stanowisko Konsultanta Krajowego w dziedzinie medycyny paliatywnej, które Pan Profesor tuczak obejmował w latach 1994-2001, następnie utworzono stanowiska Konsultantów Wojewódzkich w dziedzinie medycyny paliatywnej we wszystkich 16 województwach.Pan Profesor w 1992 roku opracował pierwszy Program Rozwoju Opieki Paliatywnej w Polsce, kolejny, opracowany przez KROPiH w 1999 roku, został przyjęty jako oficjalny dokument Ministerstwa Zdrowia. Dzięki jego staraniom wspólnie z Księdzem Eugeniuszem Dutkiewiczem, świadczenia z zakresu opieki paliatywnej zostały zakontraktowane od 1999 roku początkowo przez Kasy Chorych i wpisane do świadczeń gwarantowanych, do chwili obecnej kontraktowane przez Narodowy Fundusz Zdrowia.

W 1989 r. Pan Profesor Łuczak założył jedno z pierwszych w Polsce Stowarzyszeń, mające na celu rozwijanie opieki paliatywnej: Polskie Towarzystwo Opieki Paliatywnej im. Aleksandra Lewińskiego i Antoniny Mazur. Był wieloletnim Prezesem Zarządu Głównego do 2000 roku i od chwili utworzenia w 1996 roku do końca życia - Prezesem Oddziału Poznańskiego Polskiego Towarzystwa Opieki Paliatywnej.

\section{Działalność międzynarodowa}

Pan Profesor Jacek Łuczak brał aktywny udział w licznych spotkaniach i konferencjach międzynarodowych opieki paliatywnej. W latach 90 . był inicjatorem i organizatorem, wraz z Profesorem Robertem Twycrossem i Doktorem Michaelem Mintonem z Hospicjum Sir Michael Sobell House w Oxfordzie, ośrodka współpracującego z WHO, corocznych kursów doskonalących z zakresu opieki paliatywnej dla lekarzy i pielęgniarek z Polski i krajów Europy Środkowo-Wschodniej, na których wykładowcami były europejskie i światowe autorytety w dziedzinie opieki paliatywnej, między innymi Pan Profesor Sam $\mathrm{H}$. Ahmedzai, Pani Profesor Irene Higginson, Pani Profesor Kathleen Foley, Pan Profesor Declan Walsh, Pan Profesor Steven Passik i Pan Doktor Zbigniew Żylicz, profesor Uniwersytetu Rzeszowskiego. Łącznie w latach 19942000 w kursach tych wzięło udział około 800 uczestników: lekarzy, pielęgniarek i psychologów między innymi z Czech, Słowacji, Serbii, Chorwacji, Węgier i Rumunii.

Dzięki inicjatywie Pana Profesora Jacka Łuczaka w latach 90., ze wsparciem Polich Hospices Found i Państwa Gillian i Muir Hunter, ponad 100 lekarzy z całej Polski odbyło szkolenia w czołowych hospicjach w Wielkiej Brytanii.

Pan Profesor był inicjatorem powołania w 1999 roku Stowarzyszenia Rozwijania Opieki Paliatywnej w Europie Środkowo-Wschodniej (ECEPT, Central-Eastern Palliative Care Task Force), które prowadziło szeroką działalność edukacyjną dla lekarzy i innych pracowników powstających jednostek opieki paliatywnej, którzy uczestniczyli w kursach i odbywali staże w Klinice Opieki Paliatywnej w Poznaniu i innych wiodących ośrodkach opieki paliatywnej i hospicyjnej w Polsce. Pan Profesor pełnił obowiązki Prezesa ECEPT.

\section{Rozwój naukowy}

W 1971 roku Pan Profesor Jacek Łuczak uzyskał stopień doktora nauk medycznych za pracę „Zastosowanie fentanylu i dehydrobenzperidolu w leczeniu zawału mięśnia sercowego" [3]. W 1978 roku uzyskał stopień doktora habilitowanego nauk medycznych na podstawie rozprawy „Rola respiratora i środków stosowanych w znieczuleniu na rozległość doświadczalnego zawału serca u psów". W 1999 roku uzyskał stopień profesora nadzwyczajnego, a w 2002 roku tytuł profesora zwyczajnego.

Pan Profesor jest autorem lub współautorem około 600 prac naukowych publikowanych w polskich i zagranicznych czasopismach, promotorem 10 prac doktorskich z zakresu medycyny paliatywnej, wykształcił 3 samodzielnych pracowników nauki, w tym jednego profesora i dwóch docentów. 
W 2010 roku World Academy of Medicine nadała Panu Profesorowi Jackowi Łuczakowi tytuł doktora honoris causa.

\section{Nagrody i odznaczenia}

W 1999 roku w uznaniu zasług w rozwijaniu opieki paliatywnej i hospicyjnej otrzymał Członkostwo Królewskiego Towarzystwa Lekarskiego w Londynie (FRCP, Fellowship in Royal College of Physicians). Był nagradzany wielokrotnie prestiżowymi odznaczeniami przez Ministerstwo Zdrowia, władze miasta Poznania i inne organizacje: tytuł Wielkopolanina 1991 roku w plebiscycie Radia Merkury, w1993 r. honorowy medal im. Karola Marcinkowskiego, w 2002 roku Amicus Hominis and Veritatis, w 2003 roku „Osobowość Roku 2003 w Ochronie Zdrowia — zdrowie publiczne", w 2009 roku tytuł ECCE Homo, w 2012 roku tytuł „Człowieka Roku 2012" w plebiscycie „Liderzy medycyny" organizowanym przez Głos Wielkopolski, w 2012 r. otrzymał Europejską Nagrodę Obywatelską, w 2013 roku Wielkopolską Nagrodę imienia Ryszarda Kapuścińskiego, w 2015 roku przyznano mu tytuł Ambasadora Marki Wielkopolski, w 2016 roku Złoty Laur Akademicki, w 2017 roku został uhonorowany w konkursie Wielkopolski Lekarz z Sercem im. Kazimierza Hołogi.

$\mathrm{Na}$ szczególną uwagę zasługuje przyznana w 2014 roku Obywatelska Nagroda Parlamentu Europejskiego za zasługi w rozwoju opieki paliatywnej w Polsce i na świecie.

W dniu 14 września 2019 roku podczas Konferencji 30-lecia Polskiego Towarzystwa Opieki Paliatywnej w Poznaniu Pan Profesor Łuczak został odznaczony przez Prezydenta Rzeczypospolitej Polskiej Krzyżem Komandorskim Orderu Odrodzenia Polski.

Prawdziwym Dziełem Pana Profesora były spotkania z setkami, a może i tysiącami chorych i ich rodzin, z którymi potrafił nawiązywać wyjątkowe relacje, dbając o ich potrzeby i oczekiwania, odpowiadając na ich liczne niepokoje i wątpliwości. Potrafił przekraczać na wiele sposobów to, co wynikało jedynie z lekarskich czy akademickich obowiązków. Otwartość, umiejętność słuchania i towarzyszenia cierpiącemu człowiekowi były wyróżniającymi go cechami.

\section{Zainteresowania pozamedyczne}

Profesor Jacek Łuczak od lat 50 . był licencjonowanym Przewodnikiem po Poznaniu, zapalonym brydżystą, współzałożycielem pierwszej w Poznaniu sekcji brydża sportowego „Surma” przy poznańskiej Palmiarni. Był wiernym kibicem popularnego w Poznaniu i w Polsce, znanego także zagranicą, zespołu piłkarskiego „Kolejorza” — Lecha Poznań. Interesował się historią, szczególnie okresem kampanii wrześniowej i drugiej wojny światowej. Lubił muzykę. Swoje wykłady często wygłaszał z muzyką w tle.

\section{Pożegnanie}

Zapamiętamy Pana Profesora jak podchodził do chorych, siadał na łóżku, witał się, podając rękę, często całując pacjentów i przez długie chwile rozmawiał z nimi i ich bliskimi. Rozmowa była bardzo ważnym elementem rozpoznania i leczenia. Mówił, że „pacjent jest najważniejszy” - i tak rzeczywiście było. Był wybitnym klinicystą, o ogromnej wiedzy i intuicji lekarskiej, niezwykle uczciwym lekarzem, zawsze traktującym podmiotowo każdego pacjenta i rodzinę, całkowicie niezależnie od sytuacji rodzinnej czy materialnej. Wywarł duży wpływ na rozwój humanistycznej medycyny, nie tylko w dziedzinie opieki paliatywnej, ale całej medycyny w Polsce i zagranicą.

Pożegnanie Pana Profesora odbyło się w dniu 31 października 2019 roku na Cmentarzu Junikowskim w Poznaniu, poprzedzone Mszą Świętą odprawioną w Katedrze Poznańskiej przez Księdza Biskupa Zdzisława Fortuniaka i wielu Księży. W uroczystościach wzięło udział wiele osób reprezentujących jednostki opieki paliatywnej i hospicja z całej Polski, liczni Przedstawiciele Władz Miasta Poznania i Województwa Wielkopolskiego.

Pan Profesor pozostanie na zawsze w naszej wdzięcznej pamięci i w naszych sercach. 